\title{
Рівень та динаміка показників цитокінового профі.лю при лікуванні хворих на гостру спайкову кишкову непрохідність у стадії декомпенсації
}

\begin{abstract}
Мета роботи: вивчити динаміку про- і протизапальних цитокінів у хворих на гостру спайкову кишкову непрохідність у стадії компенсації та декомпенсації та оцінити ефективність розробленого методу комплексного післяопераційного лікування. Матеріали і методи. Обстежено 182 хворих на гостру спайкову кишкову непрохідність. 3 них 152 (83,5 \%) пацієнти були прооперовані та 30 (16,5 \%) пацієнтів проліковані консервативно (контрольна група). Пацієнтів із декомпенсованою кишковою непрохідністю кишки в післяопераційному періоді лікували традиційним і запропонованим нами способом, який включав лаваж, оксигенотерапію (Патент України на корисну модель № 81097) та ентеральне харчування через інтубаційний зонд. Лаваж кишки проводили 0,9 \% розчином $\mathrm{NaCl}$, ентеральне харчування розпочинали з появою перистальтики за допомогою розчину “Пептамен”. Також обстежено додаткову групу здорових осіб. 3 метою оцінки цитокінового статусу в сироватці крові визначали вміст TNF $\alpha$, IL1 $\beta$, IL10 методом твердофазового імуноферментного аналізу з допомогою реагентів виробництва ТОВ “Укрмедсервіс”, Україна.

Результати досліджень та їх обговорення. У пацієнтів із гострою спайковою кишковою непрохідністю у стадії декомпенсації, лікованих традиційним методом, вміст досліджуваних цитокінів (TNF $\alpha$, IЛ1ß, IL10) продовжує статистично значуще зростати до 3 доби післяопераційного періоду зі зниженням через 5 діб. Застосування розробленого нами комплексного методу післяопераційної терапії у пацієнтів з декомпенсованою гострою спайковою кишковою непрохідністю зумовлює поступове зниження вмісту цитокінів 31 до 5 доби післяопераційного періоду, що відповідає позитивній динаміці результатів загальноклінічних досліджень та суб’єктивного стану пацієнтів і свідчить про ефективність розробленого методу лікування.
\end{abstract}

Ключові слова: гостра спайкова кишкова непрохідність; цитокіни

Постановка проблеми і аналіз останніх досліджень та публікацій. Гостра спайкова кишкова непрохідність (ГСКН) належить до найтяжчих невідкладних хірургічних захворювань органів черевної порожнини $з$ високою інвалідизацією та післяопераційною нестабільністю [1]. За даними вітчизняних та зарубіжних авторів щорічна захворюваність на гостру кишкову непрохідність коливається в межах 4-5 чоловік на 100 тис. населення. На дану патологію хворіють як чоловіки, так і жінки в будь-якому віці, проте найчастіше працездатного віку - 40-60 років [2, 3]. У Сполучених Штатах Америки з приводу гострої спайкової кишкової непрохідності щорічно оперуються більше 300 тисяч пацієнтів із фінансовими затратами держави на лікування 1,3 млрд доларів, що занаходиться на одному рівні із витратами на лікування хворих на рак шлунка та прямої кишки [4].

У патогенезі гострої кишкової непрохідності лежать два основні фактори: прогресуючий ендотоксикоз і порушення метаболізму в тканинах. Пусковим механізмом ендогенної інтоксикації $€$ розвиток ентеральної дисфункції з прогресуючим дисбіозом, накопиченням бактеріальних токсинів, порушення бар’єрної функції кишок та бактеріальною транслокацією. Саме ці патогенні чинники замикають чергове “хибне” патологічне коло, пов’язане з утворенням у відповідь на про- никнення в організм патогенів, антигенне подразнення або пошкодження тканин медіаторів запалення - цитокінів. Одним із найсильніших індукторів синтезу цитокінів вважають компоненти клітинних стінок бактерій: ліпополісахариди, пептидоглікани і мурамілдипептиди $[5,6]$.

При вираженому запаленні черевної порожнини такі цитокіни, як фактор некрозу пухлин $\alpha$ (TNFa), інтерлейкіни 1ß, 6, 10 (IL1ß, IL6 відповдіно) можуть проникати в системну циркуляцію, накопичуватися там в кількості, достатній для реалізації ушкоджувальних ефектів. У разі нездатності регулюючих систем до підтримки гомеостазу, деструктивні ефекти цитокінів та інших медіаторів починають домінувати, що призводить до порушення проникності і функції ендотелію капілярів, запуску синдрому дисемінованого внутрішньосудинного згортання, формування віддалених вогнищ запалення, розвитку моно- і поліорганної дисфункції [7, 8].

У зв'язку з цим, спостереження в динаміці хворих на ГСКН за вмістом про- і протизапальних цитокінів дає важливу інформацію про розвиток патологічного процесу та ефективність методів лікування.

Мета роботи: вивчити динаміку про- і протизапальних цитокінів у хворих на ГСКН у стадії декомпенсації та оцінити ефективність розробленого методу комплексного післяопераційного лікування. 
Матеріали і методи. Проаналізовано результати клінічного обстеження, консервативного та хірургічного лікування 182 хворих на ГСКН. 3 них 152 (83,5 \%) пацієнти були прооперовані та 30 (16,5 \%) пацієнтів проліковані консервативно. Чоловіків було 83 (45,6 \%), жінок - 99 (54,4 \%). Вік обстежених коливався від 20 до 85 років. Середній вік становив $(53,6 \pm 0,6)$ року.

Обстежені хворі були розподілені на 4 групи 3 основні та контрольну. В основну групу 1 ввійшли пацієнти в стадії компенсації, яким було виконано роз'єднання спайок та дренування черевної порожнини. В основну групу 2 ввійшли пацієнти в стадії декомпенсації, яким після ліквідації причини кишкової непрохідності інтраопераційно виконували назогастроінтестинальну інтубацію (НГІІ). Пацієнтам цієї групи в післяопераційному періоді інтубаційний зонд використовували лише для декомпресії та пасивного відтоку кишкового вмісту. Основну групу 3 склали пацієнти в стадії декомпенсації, яким після ліквідації причини кишкової непрохідності інтраопераційно НГІІ. В післяопераційному періоді пацієнтам цієї групи інтубаційний зонд використовували для проведення лаважу, оксигенотерапії (Патент України на корисну модель № 81097) та ентерального харчування. Лаваж кишки проводили 0,9 \% розчином $\mathrm{NaCl}$, ентеральне харчування розпочинали з появою перистальтики за допомогою розчину “Пептамен”. Контрольну групу склали неоперовані хворі в стадії компенсації, в яких кишкова непрохідність усунули консервативно. В комплексі консервативної терапії пацієнтів цієї групи для декомпресії шлунка використовували назогастральний зонд. Додаткову контрольну групу з метою вивчення і порівняння лабораторних показників склали 15 здорових осіб, в яких на момент обстеження не виявлено патології.

У всіх хворих визначали необхідні загальноклінічні та біохімічні показники на етапі госпіталізації, через 1, 3 і 5 діб лікування. Для оцінки цитокінового статусу в сироватці крові визначали вміст TNF $\alpha$, IL1 $\beta$, IL10 методом твердофазового імуноферментного аналізу з допомогою реагентів виробництва ТОВ “Укрмедсервіс”, Україна.

Отримані цифрові дані обробляли статистично. Вірогідність відмінностей між дослідними і контрольною групами оцінювали з використанням програми STATISTICA (“StatSoft, Inc.”, США) на основі непараметричного критерію Манна-Уїтні.

Результати досліджень та їх обговорення. Як відображено в таблиці 1, у контрольній групі при госпіталізації порівняно зі здоровими спосте-

Таблиця 1. Вплив комплексного лікування на вміст у сироватці крові IL1ß (пг/мл) у хворих із гострою

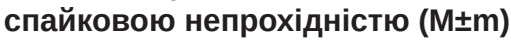

\begin{tabular}{|c|c|c|c|c|c|}
\hline \multirow{2}{*}{$\begin{array}{c}\text { Групи } \\
\text { хворих }\end{array}$} & \multirow{2}{*}{$\begin{array}{c}\text { Здорові } \\
(n=15)\end{array}$} & \multirow{2}{*}{$\begin{array}{c}\text { При } \\
\text { госпіталізації }\end{array}$} & \multicolumn{3}{|c|}{ Термін спостереження } \\
\hline & & & 1 доба & 3 доба & 5 доба \\
\hline $\begin{array}{l}\text { Контрольна } \\
(n=30)\end{array}$ & \multirow[t]{4}{*}{$\begin{array}{c}2,40 \pm \\
0,02\end{array}$} & $\begin{array}{l}3,64 \pm \\
0,07^{*}\end{array}$ & $\begin{array}{l}3,40 \pm \\
0,06^{*_{r}}\end{array}$ & $\begin{array}{l}3,39 \pm \\
0,06^{*_{\Gamma}}\end{array}$ & $\begin{array}{c}2,67 \pm \\
0,06^{*}{ }^{*}, 1,3\end{array}$ \\
\hline $\begin{array}{l}\text { Основна } 1 \\
(n=58)\end{array}$ & & $\begin{array}{l}3,97 \pm \\
0,07^{* \#}\end{array}$ & $\begin{array}{l}3,80 \pm \\
0,07^{* \#}\end{array}$ & $\begin{array}{l}3,69 \pm \\
0,07^{* \# \Gamma}\end{array}$ & $\begin{array}{c}3,08 \pm \\
0,07^{* \# \Gamma, 1,3}\end{array}$ \\
\hline $\begin{array}{l}\text { Основна } 2 \\
(n=49)\end{array}$ & & $\begin{array}{l}4,67 \pm \\
0,09^{* \#}\end{array}$ & $\begin{array}{l}5,12 \pm \\
0,11^{* \# \mathrm{r}}\end{array}$ & $\begin{array}{c}5,69 \pm \\
0,10^{* \#+1}\end{array}$ & $\begin{array}{c}5,28 \pm \\
0,10^{* \#+3}\end{array}$ \\
\hline $\begin{array}{l}\text { Основна } 3 \\
(n=45)\end{array}$ & & $\begin{array}{l}5,00 \pm \\
0,10^{* \#}\end{array}$ & $\begin{array}{l}5,25 \pm \\
0,11^{* \#}\end{array}$ & $\begin{array}{l}5,12 \pm \\
0,11^{* \#}\end{array}$ & $\begin{array}{c}3,44 \pm \\
0,04^{* \# r, 1,3}\end{array}$ \\
\hline \multicolumn{2}{|c|}{$\mathrm{p}_{1-2}$} & $<0,05$ & $<0,05$ & $<0,05$ & $<0,05$ \\
\hline \multicolumn{2}{|c|}{$\mathrm{p}_{1-3}$} & $<0,05$ & $<0,05$ & $<0,05$ & $<0,05$ \\
\hline \multicolumn{2}{|c|}{$\mathrm{p}_{2-3}$} & $<0,05$ & $>0,05$ & $<0,05$ & $<0,05$ \\
\hline
\end{tabular}

Примітки. Тут і в таблицях 2 і 3:

* - відмінності стосовно здорових статистично вірогідні $(\mathrm{p}<0,05)$;

\# - відмінності стосовно контрольної групи статистично вірогідні (p<0,05);

$\mathrm{p}_{1-2}-$ вірогідність відмінностей між основними групами 1 і 2;

$\mathrm{p}_{1-3}$ - вірогідність відмінностей між основними групами 1 і 3;

$\mathrm{p}_{2-3}$ - вірогідність відмінностей між основними групами 2 і 3;

r,1,3 - відмінності стосовно терміну відповідно при госпіталізації, на 1 і 3 доби лікування статистично вірогідні (p<0,05). 
рігали підвищений вміст IL $1 \beta$ у сироватці крові на $51,7 \%$ (р<0,05). В динаміці лікування через $1-$ 5 діб відбулося зниження рівня цього показника, проте статистично достовірно його рівень перевищував рівень здорових: через 1 добу - на 41,7 \% $(\mathrm{p}<0,05)$, через 3 доби - на 41,3 \% ( $<0,05)$, через 5 діб - на 11,3 \% (p<0,05). Через 5 діб досліджуваний показник ставав меншим, ніж при госпіталізації, через 1 і 3 доби лікування (на 26,6, 21,5 і 21,2 \% відповідно, $\mathrm{p}<0,05)$.

В основній групі 1 при госпіталізації вміст IL1 $\beta$ в сироватці крові був підвищеним порівняно зі здоровими на 65,4 \% (p<0,05). Через 1-5 діб після операції його динаміка була подібна до контрольної групи - спостерігали зниження рівня цього показника, проте він статистично достовірно перевищував рівень здорових: через 1 добу - на $58,3 \%(\mathrm{p}<0,05)$, через 3 доби на - 53,8 \% $(\mathrm{p}<0,05)$, через 5 діб на - 28,3 \% (p<0,05). Через 5 діб рівень IL1 $\beta$ ставав меншим, ніж при госпіталізації, через 1 і 3 доби лікування (на 22,4, 18,9 і 16,5 \% відповідно, $\mathrm{p}<0,05)$.

В основній групі 2 рівень досліджуваного показника при госпіталізації порівняно зі здоровими був підвищений - на 94,6 \% (p<0,05). Через 1 та 3 доби після операції спостерігалось зростання його рівня відносно рівня групи здорових: через 1 добу - у 2,13 раза $(\mathrm{p}<0,05)$, через 3 доби - у 2,37 paза $(\mathrm{p}<0,05)$. Через 5 діб цей показник знижувався, проте статистично достовірно перевищував рівень здорових - у 2,20 раза $(\mathrm{p}<0,05)$. Через 5 діб рівень IL1 $\beta$ ставав меншим, ніж при госпіталізації, через 3 доби лікування (на 13,1 і 7,2 \% відповідно, $\mathrm{p}<0,05)$.

Серед пацієнтів основної групи 3 при госпіталізації вміст IL1 $\beta$ в сироватці крові був підвищений - у 2,08 раза $(\mathrm{p}<0,05)$. Через 1 добу післяопераційного періоду спостерігалось зростання його рівня - у 2,18 раза $(\mathrm{p}<0,05)$. В динаміці подальшого лікування його рівень знижувався до 5 доби, проте статистично вірогідно перевищував рівень здорових: через 3 доби - у 2,13 раза $(\mathrm{p}<0,05)$, а через 5 діб - на 43,3 \% (p<0,05). Привертає увагу факт, що досліджуваний показник досягаючи мінімального рівня через 5 діб лікування виявився істотно меншим, ніж при госпіталізації на $31,2 \%(\mathrm{p}<0,05)$ та порівняно 3 попередніми термінами спостереження (на 34,5 і 32,8 \% відповідно, $\mathrm{p}<0,05)$.

При порівнянні вмісту IL $1 \beta$ в сироватці крові між основними групами і контрольною встановлено, що і при госпіталізації, і в динаміці лікування в основних групах даний показник виявився статистично вірогідно більшим $(\mathrm{p}<0,05)$. При по- рівнянні між собою основних груп на етапі госпіталізації та в динаміці лікування встановлено наступне. При госпіталізації найбільший рівень IL1 $\beta$ спостерігали в основних групах 2 і 3, порівняно з основною групою 1 (на 17,6 і 25,9 \%, відповідно, $\left.\mathrm{p}_{1-2}<0,05, \mathrm{p}_{1-3}<0,05\right)$. В ході лікування через 1 добу рівень досліджуваного показника так само був найбільшим в основних групах 2 і 3 порівняно з основною групою 1 (на 34,7 і 38,2 \%, відповідно, $\left.\mathrm{p}_{1-2}<0,05, \mathrm{p}_{1-3}<0,05\right)$. В цих групах досліджуваний показник був практично однаковим $\left(\mathrm{p}_{2-3}>0,05\right)$. Через 3 доби лікування цей показник залишався вірогідно меншим в основній групі 1 (на 54,2 \% порівняно з основною групою 2, $\mathrm{p}_{1-2}<0,05$ та на 38,7 \% порівняно 3 основою групою $\left.3, \mathrm{p}_{1-3}<0,05\right)$. Також встановлено, що в даний термін в основній групі 3 рівень IL1 $\beta$ був статистично вірогідно меншим, ніж в основній групі 2 (на $\left.11,1 \%, \mathrm{p}_{2-3}<0,05\right)$. Через 5 діб лікування величина досліджуваного показника в основних групах зменшувалася, проте він залишався нижчим в основній групі 1 (на 71,4 \% порівняно з основною групою $2, \mathrm{p}_{1-2}<0,05$ та на $11,7 \%$ меншим порівняно $з$ основною групою 3, $\left.\mathrm{p}_{1-3}<0,05\right)$. В основній групі 3 внаслідок використаного способу лікування показник був меншим, ніж в основній групі 2, де в післяопераційному періоді проводилось традиційне лікування (на $\left.53,5 \%, \mathrm{p}_{2-3}<0,05\right)$.

Таким чином, при госпіталізації у хворих 3 ГСКН спостерігається збільшення концентрації в сироватці крові IL1ß. У подальшому до 5 доби в контрольній та основній групі 1 показник знижується, не досягаючи рівня контролю, тоді як у хворих з декомпенсованою кишковою непрохідністю через 1 добу після операції він, навпаки, зростає. За цих умовах, у хворих основної групи 3 (запропонований метод лікування) показник до 5 доби істотно знижується і стає суттєво меншим, ніж в основній групі 2 (традиційний метод лікування).

За даними таблиці 2, у контрольній групі пацієнтів при госпіталізації порівняно зі здоровими спостерігався підвищений вміст TNF $\alpha$ у сироватці крові - на 91,9 \% $(\mathrm{p}<0,05)$. У процесі лікування на 1 та 3 добу після госпіталізації показник зростав і ставав вищим від рівня здорових: на 1 добу на 96,8 \% ( $<<0,05)$, на 3 добу - у 2,05 раза ( $<00,05)$. У подальшому до 5 доби рівень цього показника знижувався, проте статистично вірогідно перевищував рівень здорових - на 79 \% $(\mathrm{p}<0,05)$. Через 5 діб рівень TNF $\alpha$ ставав меншим, ніж при госпіталізації, через 1 та 3 доби лікування (на 6,7, 9,0 і 12,6 \% відповідно, $\mathrm{p}<0,05)$.

В основній групі 1 при госпіталізації вміст TNF $\alpha$ в сироватці крові був підвищеним порівня- 
но зі здоровими у 2,19 раза $(\mathrm{p}<0,05)$. Через 1 добу після операції спостерігалось зростання рівня цього показника - у 2,96 раза $(\mathrm{p}<0,05)$. В подальшому показник поступово знижувався, проте статистично достовірно перевищував рівень здорових: через 3 доби - у 2,61 раза ( $<0,05)$, через 5 діб - y 2,39 раза $(\mathrm{p}<0,05)$. Через 5 діб рівень TNF $\alpha$ ставав меншим, ніж при госпіталізації, через 1 та 3 доби лікування (на 8,8, 19,6 і 8,6 \% відповідно, p<0,05).

В основній групі 2 рівень досліджуваного показника при госпіталізації порівняно зі здоровими був підвищений у $-5,16$ раза $(\mathrm{p}<0,05)$. На 1 та 3 добу після операції спостерігалось зростання його рівня відносно рівня групи здорових (у 7,48 і 7,63 раза (p<0,05). Через 5 діб цей показник знижувався, проте статистично достовірно перевищував рівень здорових - у 6,53 раза (p<0,05). Через 5 діб лікування рівень досліджуваного показника ставав меншим, ніж при госпіталізації, через 1 та 3 доби лікування (на 26,6, 12,7 і 14,4 \% відповідно, p<0,05).

Серед пацієнтів основної групи 3 при госпіталізації вміст TNF $\alpha$ в сироватці крові був підвищеним порівняно зі здоровими особами - у 5,35 раза $(\mathrm{p}<0,05)$. Через 1 добу післяопераційного періоду спостерігалось зростання його рівня - у 6,37 раза $(\mathrm{p}<0,05)$. В динаміці подальшого лікування його рівень знижувався до 5 доби, проте статистично вірогідно перевищував рівень здорових: через 3 доби - у 5,74 раза (p<0,05), через 5 діб - у 4,63 раза $(\mathrm{p}<0,05)$. Досягаючи мінімального рівня через 5 діб показник виявився статистично вірогідно меншим, ніж при госпіталізації, через 1 та 3 доби лікування (на 13,5, 27,3 і 19,4 \% відповідно, p<0,05).
При порівнянні вмісту TNF $\alpha$ в сироватці крові між основними групами і контрольною, встановлено, що і при госпіталізації, і в динаміці лікування в основних групах даний показник виявився статистично вірогідно більшим $(\mathrm{p}<0,05)$. При порівнянні між собою основних груп на етапі госпіталізації та в динаміці лікування встановлено наступне. При госпіталізації найбільший рівень TNF $\alpha$ спостерігали в основних групах 2 і 3, порівняно з основною групою 1 (у 2,35 і 2,44 раза, відповідно, $\left.\mathrm{p}_{1-2}<0,05, \mathrm{p}_{1-3}<0,05\right)$. В ході лікування через 1 добу рівень досліджуваного показника так само виявили найбільшим в основних групах 2 і 3 порівняно з основною групою 1 (у 2,52 і 2,15 раза відповідно, $\left.\mathrm{p}_{1-2}<0,05, \mathrm{p}_{1-3}<0,05\right)$. Через 3 доби лікування цей показник залишався вірогідно меншим в основній групі 1 (у 2,91 раза порівняно з основною групою 2, $\mathrm{p}_{1-2}<0,05$ та у 2,20 раза порівняно з основою групою $\left.3, \mathrm{p}_{1-3}<0,05\right)$. Також встановлено, що в даний термін в основній групі 3 рівень TNF $\alpha$ був статистично вірогідно меншим, ніж в основній групі 2 (на 35,9 \%, $\left.\mathrm{p}_{2-3}<0,05\right)$. Через 5 діб лікування величина досліджуваного показника в основних групах зменшувалася, проте він залишався нижчим в основній групі 1 (у 2,74 раза порівняно з основною групою 2, $\mathrm{p}_{1-2}<0,05$ та на 93,9 \% меншим порівняно з основною групою $\left.3, \mathrm{p}_{1-3}<0,05\right)$. В основній групі 3 внаслідок використаного способу лікування показник був меншим, ніж в основній групі 2, де в післяопераційному періоді проводилось традиційне лікування (на 41,1 \%, $\mathrm{p}_{2-3}<0,05$ ).

Таким чином, у пацієнтів з гострою хірургічною патологією при госпіталізації у сироват-

Таблиця 2. Вплив комплексного лікування на вміст у сироватці крові TNF $\alpha$ (пг/мл) у хворих із гострою

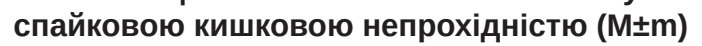

\begin{tabular}{|c|c|c|c|c|c|}
\hline \multirow{2}{*}{$\begin{array}{c}\text { Групи } \\
\text { хворих }\end{array}$} & \multirow{2}{*}{$\begin{array}{c}\text { Здорові } \\
(\mathrm{n}=15)\end{array}$} & \multirow{2}{*}{$\begin{array}{c}\text { При } \\
\text { госпіталізації }\end{array}$} & \multicolumn{3}{|c|}{ Термін спостереження } \\
\hline & & & 1 доба & 3 доба & 5 доба \\
\hline $\begin{array}{l}\text { Контрольна } \\
(\mathrm{n}=30)\end{array}$ & \multirow{4}{*}{$\begin{array}{c}0,62 \pm \\
0,03\end{array}$} & $\begin{array}{l}1,19 \pm \\
0,02^{*}\end{array}$ & $\begin{array}{l}1,22 \pm \\
0,02^{*}\end{array}$ & $\begin{array}{l}1,27 \pm \\
0,02^{* \mathrm{r}}\end{array}$ & $\begin{array}{c}1,11 \pm \\
0,03^{*_{\mathrm{r}, 1,3}}\end{array}$ \\
\hline $\begin{array}{l}\text { Основна } 1 \\
(\mathrm{n}=58)\end{array}$ & & $\begin{array}{l}1,36 \pm \\
0,01^{* *}\end{array}$ & $\begin{array}{l}1,84 \pm \\
0,02^{* \# \mathrm{r}}\end{array}$ & $\begin{array}{c}1,62 \pm \\
0,03^{* \#, 1}\end{array}$ & $\begin{array}{c}1,48 \pm \\
0,01^{* \#, 1,1,3}\end{array}$ \\
\hline $\begin{array}{l}\text { Основна } 2 \\
(\mathrm{n}=49)\end{array}$ & & $\begin{array}{l}3,20 \pm \\
0,09^{* *}\end{array}$ & $\begin{array}{l}4,64 \pm \\
0,13^{* * 1+r}\end{array}$ & $\begin{array}{l}4,73 \pm \\
0,12^{* * \mathrm{r}}\end{array}$ & $\begin{array}{c}4,05 \pm \\
0,06^{* \#,+1,3}\end{array}$ \\
\hline $\begin{array}{l}\text { Основна } 3 \\
(\mathrm{n}=45)\end{array}$ & & $\begin{array}{l}3,32 \pm \\
0,10^{* *}\end{array}$ & $\begin{array}{l}3,95 \pm \\
0,11^{* \text { *Ir }}\end{array}$ & $\begin{array}{c}3,56 \pm \\
0,09^{* * 11}\end{array}$ & $\begin{array}{c}2,87 \pm \\
0,04^{* \#, 1,1,3}\end{array}$ \\
\hline \multicolumn{2}{|c|}{$\mathrm{p}_{1-2}$} & $<0,05$ & $<0,05$ & $<0,05$ & $<0,05$ \\
\hline \multicolumn{2}{|c|}{$\mathrm{P}_{1-3}$} & $<0,05$ & $<0,05$ & $<0,05$ & $<0,05$ \\
\hline \multicolumn{2}{|c|}{$\mathrm{p}_{2-3}$} & $>0,05$ & $<0,05$ & $<0,05$ & $<0,05$ \\
\hline
\end{tabular}


ці крові спостерігається підвищений вміст TNF $\alpha$. Через 1 добу після операції показник в основних групах зростає. Проте в основній групі 1 він поступово знижується, не досягаючи рівня контролю. В основній групі 2 він продовжує збільшуватися до 3 доби з наступним зниженням, в той час, як в основній групі 3 показник поступово знижується $з 1$ до 5 діб посттравматичного періоду і в ці терміни статистично вірогідно менший, ніж в основній групі 2.

За даними таблиці 3, у контрольній групі при госпіталізації порівняно зі здоровими спостерігається підвищений вміст IL10 у сироватці крові на 8,5 \% (p<0,05). Через $1-5$ діб лікування відбулося зростання рівня цього показника: через 1 добу - на 10,7 \% (p<0,05), через 3 доби - на 13,9 \% $(\mathrm{p}<0,05)$, через 5 діб - на $19 \%(\mathrm{p}<0,05)$. Через 5 діб лікування рівень досліджуваного показника ставав більшим, ніж при госпіталізації, через 1 та 3 доби лікування (на 9,7, 7,5 і 4,5 \%, відповідно, $\mathrm{p}<0,05)$.

В основній групі 1 при госпіталізації вміст ІЛ-10 в сироватці крові був підвищений порівняно зі здоровими на 13,9 \% $(\mathrm{p}<0,05)$. В динаміці лікування через $1-3$ доби спостерігалося зростання рівня цього показника (на 22,2 і 32,5 \% відповідно $(\mathrm{p}<0,05))$. Через 3 доби після операції показник ставав більшим ніж при госпіталізації та через 1 добу (на 16,3 і 8,4 \%, відповідно, p<0,05). Через 5 діб лікування досліджуваний показник поступово знижувався, проте статистично достовірно перевищував рівень здорових - на 27,4 \% $(\mathrm{p}<0,05)$, але був меншим, ніж при госпіталізації на 11,8 \% (p<0,05).
В основній групі 2 рівень досліджуваного показника при госпіталізації порівняно зі здоровими був підвищеним на 15,5 \% ( $<0,05)$. На 1-5 доби після операції спостерігалось зростання його рівня відносно рівня групи здорових (на 22,2, 66,9 \% i $2,28$ раза відповідно, $(\mathrm{p}<0,05))$. Через 5 діб лікування рівень досліджуваного показника ставав більшим, ніж при госпіталізації, через 1 та 3 доби лікування (на 97,5, 86,6 і 36,7 \% відповідно, p<0,05).

Серед пацієнтів основної групи 3 при госпіталізації вміст IL10 в сироватці крові був підвищений на 19,4 \% (p<0,05). Через 1 та 3 доби післяопераційного періоду спостерігалось зростання його рівня відносно групи здорових: через 1 добу - на $32,6 \%(\mathrm{p}<0,05)$, через 3 доби - на 83,4 \% ( $<0,05)$. Досягаючи мінімального рівня через 5 діб, показник статистично вірогідно перевищував рівень здорових - на 30,7 \% ( $<0,05)$, але був менший, ніж при госпіталізації та через 3 доби лікування (на 9,5 і 28,7 \% відповідно, р<0,05).

При порівнянні вмісту IL10 в сироватці крові між основними групами і контрольною встановлено, що і при госпіталізації, і в динаміці лікування в основних групах даний показник виявився статистично вірогідно більшим ( $<0,05)$. При порівнянні між собою основних груп на етапі госпіталізації та в динаміці лікування встановлено, що при госпіталізації та через 1 добу після операції найбільший рівень IL10 спостерігали в основній групі 3, порівняно $з$ основною групою $1\left(\mathrm{p}_{1-3}<0,05\right)$, в групах 1 та 2 показник був приблизно однаковим у дані терміни спостереження $\left(\mathrm{p}_{1-2}>0,05\right)$. Однак через 3 доби лікування цей показник був вірогідно меншим в

Таблиця 3. Вплив комплексного лікування на вміст у сироватці крові IL10 (пг/мл) у хворих із гострою

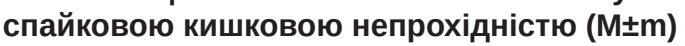

\begin{tabular}{|c|c|c|c|c|c|}
\hline \multirow{2}{*}{$\begin{array}{c}\text { Групи } \\
\text { хворих }\end{array}$} & \multirow{2}{*}{$\begin{array}{c}\text { Здорові } \\
(\mathrm{n}=15)\end{array}$} & \multirow{2}{*}{$\begin{array}{c}\text { При } \\
\text { госпіталізації }\end{array}$} & \multicolumn{3}{|c|}{ Термін спостереження } \\
\hline & & & 1 доба & 3 доба & 5 доба \\
\hline $\begin{array}{l}\text { Контрольна } \\
(\mathrm{n}=30)\end{array}$ & \multirow{4}{*}{$\begin{array}{c}6,25 \pm \\
0,02\end{array}$} & $\begin{array}{l}6,78 \pm \\
0,12^{*}\end{array}$ & $\begin{array}{c}6,92 \pm \\
0,11^{*}\end{array}$ & $\begin{array}{c}7,12 \pm \\
0,13^{*}\end{array}$ & $\begin{array}{c}7,44 \pm \\
0,07^{*_{\mathrm{r}}, 1,3}\end{array}$ \\
\hline $\begin{array}{l}\text { Основна } 1 \\
(\mathrm{n}=58)\end{array}$ & & $\begin{array}{l}7,12 \pm \\
0,08^{* \#}\end{array}$ & $\begin{array}{l}7,64 \pm \\
0,13^{* \# \mathrm{r}}\end{array}$ & $\begin{array}{c}8,28 \pm \\
0,10^{* \# \mathrm{r}, 1}\end{array}$ & $\begin{array}{l}7,96 \pm \\
0,13^{* \# \mathrm{r}}\end{array}$ \\
\hline $\begin{array}{l}\text { Основна } 2 \\
(n=49)\end{array}$ & & $\begin{array}{l}7,22 \pm \\
0,14^{* *}\end{array}$ & $\begin{array}{l}7,64 \pm \\
0,13^{* \# \mathrm{r}}\end{array}$ & $\begin{array}{l}10,43 \pm \\
0,16^{* \# \mathrm{r}, 1}\end{array}$ & $\begin{array}{c}14,26 \pm \\
0,15^{* * ⿰ 氵, 1,3}\end{array}$ \\
\hline $\begin{array}{l}\text { Основна } 3 \\
(\mathrm{n}=45)\end{array}$ & & $\begin{array}{l}7,46 \pm \\
0,14^{* *}\end{array}$ & $\begin{array}{l}8,29 \pm \\
0,21^{* \# \mathrm{H}}\end{array}$ & $\begin{array}{l}11,46 \pm \\
0,23^{* * \mathrm{H}, 1}\end{array}$ & $\begin{array}{c}8,17 \pm \\
0,09^{*} \neq 1,3\end{array}$ \\
\hline \multicolumn{2}{|c|}{$\mathrm{p}_{1-2}$} & $>0,05$ & $>0,05$ & $<0,05$ & $<0,05$ \\
\hline \multicolumn{2}{|c|}{$\mathrm{p}_{1-3}$} & $<0,05$ & $<0,05$ & $<0,05$ & $>0,05$ \\
\hline \multicolumn{2}{|c|}{$\mathrm{p}_{2-3}$} & $>0,05$ & $<0,05$ & $<0,05$ & $<0,05$ \\
\hline
\end{tabular}


основній групі 1 на 26 \% порівняно з основною групою $2\left(\mathrm{p}_{1-2}<0,05\right)$ та на $38,4 \%$ порівняно з основою групою $3\left(\mathrm{p}_{1-3}<0,05\right)$. Привертає увагу факт, що через 5 діб лікування рівень досліджуваного показника в основній групі 2 продовжував зростати та перевищував його рівень в основній групі 1 на 79,1 \% $\mathrm{p}_{1-2}<0,05$ та на $74,5 \%$ в основній групі $3\left(\mathrm{p}_{1-2}<0,05\right)$.

Таким чином, на момент госпіталізації у сироватці крові обстежених хворих суттєво більший вміст IL10, який в контрольній групі поступово зростає 31 до 5 діб після операції. В основній групі 1 показник теж зростає, досягаючи максимуму через 3 доби з наступним зниженням. В основній групі 2 (традиційне лікування) він до 5 доби значно збільшується, тоді як в основній групі 3 (запропонований метод лікування) показник до 3 доби зростає з наступним зниженням до 5 доби. Через 1 і 3 доби в цій групі вміст IL10 істотно перевищує основну групу 2, проте через 5 діб, навпаки, стає меншим.

Отримані результати свідчать про те, що в основній групі 1 (ГСКН у стадії компенсації) динаміка вмісту в сироватці крові про- і протизапальних цитокінів має функціональний характер з максимумом в момент госпіталізації та оперативного лікування і наступним суттєвим зниженням до 5 доби післяопераційного періоду. У той же час у пацієнтів основної групи 2 і 3 (ГСКН у стадії декомпенсації) вже при госпіталізації вміст досліджуваних цитокінів у сироватці крові $є$ істотно більшим, ніж у пацієнтів основної групи 1, що вказує на виражену системну відповідь організму на запалення.

\section{СПИСОК ЛІТЕРАТУРИ}

1. Оптимізація лікувальної тактики у хворих на гостру тонкокишкову непрохідність залежно від ступеня розвитку ентерергії кишечнику / В. Д. Скрипко, Ю. А. Клименко, А. О. Клименко, М. Г. Гончар // Буковинський медичний вісник. - 2014. - Т. 18, № 1. - С. 110-114.

2. Евтушенко Д. А. Прогнозирование и профилактика рецидива образования спаек после операции у пациентов при спаечной болезни брюшины, осложненной острой непроходимостью кишечника / Д. А. Евтушенко // Клінічна хірургія. - 2015. - № 1. - С. 13-15.

3. A prospective randomized trial of transnasal ileus tube vs nasogastric tube for adhesive small bowel obstruction / X. L. Chen, F. Ji, Q. Lin [et al.] // World J. Gastroenterol. - 2012. - Vol. 28, No. 18. - P. 1968-1974.

4. A protocol for the management of adhesive small bowel obstruction / T. Loftus, F. Moore, E. VanZant [et al.] // J. Trauma Acute Care Surg. - 2015. - Vol. 78. - P. 13-19.
При лікуванні хворих $з$ декомпенсованою ГСКН традиційним методом вміст досліджуваних цитокінів продовжує статистично значуще зростати до 3 доби після операції зі зниженням через 5 діб. Застосування розробленого нами комплексного методу післяопераційної терапії (основна група 3) зумовлює поступове зниження вмісту цитокінів 31 до 5 доби післяопераційного періоду. Цей результат відповідає позитивній динаміці загальноклінічних даних та суб'єктивного стану пацієнтів, що дозволяє його трактувати як ознаку зниження системної реакції організму на запалення й додатково доводить ефективність запропонованого методу комплексної післяопераційної терапії.

Висновки. 1. В основній групі 1 (ГСКН у стадії компенсації) динаміка вмісту в сироватці крові про- і протизапальних цитокінів (TNFa, IL1 $\beta$, IL10) має функціональний характер із максимумом у момент госпіталізації та оперативного лікування і наступним суттєвим зниженням до 5 доби післяопераційного періоду.

2. У пацієнтів основної групи 2 (ГСКН у стадії декомпенсації), лікованих традиційним методом, вміст досліджуваних цитокінів продовжує статистично значуще зростати до 3 доби післяопераційного періоду зі зниженням через 5 діб. Застосування розробленого нами комплексного методу післяопераційної терапії (основна група 3) навіть на тлі вихідної декомпенсованої ГСКН зумовлює поступове зниження вмісту цитокінів з 1 до 5 доби післяопераційного періоду.

5. Климанский Р. П. Прогностические иммунные маркеры, определяющие течение послеоперационного периода у детей с врожденной кишечной непроходимостью / Р. П. Климанский, С. В. Веселый // Медична інформатика та інженерія. - 2016. - № 1. - С. 79-80.

6. New paradigms in the treatment of small bowel obstruction / M. T. Dayton, D. T. Dempsey, G. M. Larson, A. R. Posner // Curr. Probl. Surg. - 2012. - Vol. 49, No. 11. - P. 642-717.

7. Олейник А. Е. Динамика морфологических изменений стенки тонкой кишки при моделировании острой кишечной непроходимости. Оценка протективного действия различных антибиотиков / А. Е. Олейник // Вісник проблем біології і медицини. - 2014. - С. 299-303.

8. Андрющенко В. П. Клінічні та патоморфологічні прояви синдрому недостатності кишечнику в перебігу гострого некротичного панкреатиту / В. П. Андрющенко, В. В. Куновський, Д. В. Андрющенко // Харківська хірургічна школа. 2014. - № 3. - С. 5-7. 


\section{REFERENCES}

1. Skrypko, V.D., Klymenko, Yu.A., Klymenko, A.O., \& Honchar, M.H. (2014). Optymizatsiia likuvalnoi taktyky u khvorykh na hostru tonkokyshkovu neprokhidnist zalezhno vid stupenia rozvytku entererhii kyshechnyku [Optimization of therapeutic tactics in patients with acute small intestinal obstruction depending on the degree of intestinal enterology development]. Bukovynskyi medychnyi visnyk - Bukovyna Medical Bulletin, 18, 1, 110-114 [in Ukrainian].

2. Yevtushenko, D.A. (2015). Prognozirovaniye i profilaktika retsidiva obrazovaniya spayek posle operatsii u patsiyentov pri spayechnoy bolezni bryushiny, oslozhnennoy ostroy neprokhodimostyu kishechnika [Prediction and prevention of relapse in the formation of adhesions after surgery in patients with adhesive disease of the peritoneum complicated by acute intestinal obstruction]. Klinichna khirurhiia - Clinical Surgery, 1, 13-15 [in Russian].

3. Chen, X.L., Ji, F., Lin, Q., Chen, Y.P., Lin, J.J., Ye, F., Yu, J.R., \& Wu, Y.J. (2012). A prospective randomized trial of transnasal ileus tube vs nasogastric tube for adhesive small bowel obstruction. World J. Gastroenterol, 28, 18, 1968-1974.

4. Loftus, T., Moore, F., VanZant, E., Bala, T., Brakenridge, S., Croft, C., ..., \& Jordan, J. (2015). A protocol for the management of adhesive small bowel obstruction. J. Trauma Acute Care Surg., 78, 13-19.

5. Klimanskiy, R.P., \& Veselyy, S.V. (2016). Prognosticheskiye immunnyye markery, opredelyayushchiye techeniye posleoperatsionnogo perioda u detey s vrozhdennoy kishechnoy neprokhodimostyu [Prognostic immune markers that determine the course of the postoperative period in children with congenital intestinal obstruction]. Medychna informatyka ta inzheneriia - Medical Informatics and Engineering, 1, 79-80 [in Russian].

6. Dayton, M.T., Dempsey, D.T., Larson, G.M., \& Posner, A.R. (2012). New paradigms in the treatment of small bowel obstruction. Curr. Probl. Surg., 49, 11, 642-717.

7. Oleynik, A.Ye. (2014). Dinamika morfologicheskikh izmeneniy stenki tonkoy kishki pri modelirovanii ostroy kishechnoy neprokhodimosti. Otsenka protektivnogo deystviya razlichnykh antibiotikov [Dynamics of morphological changes in the wall of the small intestine during modeling of acute intestinal obstruction. Evaluation of the protective effect of various antibiotics]. Visnyk problem biolohii i medytsyny - Bulletin of Problems of Biology and Medicine, 1 (106), 299-303 [in Russian].

8. Andriushchenko, V.P., Kunovskyi, V.V., \& Andriushchenko, D.V. (2014). Klinichni ta patomorfolohichni proiavy syndromu nedostatnosti kyshechnyku v perebihu hostroho nekrotychnoho pankreatytu [Clinical and pathomorphological manifestations of bowel deficiency syndrome in the course of acute necrotic pancreatitis]. Kharkivska khirurhichna shkola - Kharkiv Surgical School, 3, 5-7 [in Ukrainian].

\title{
THE LEVEL AND DYNAMICS OF INDICATORS OF CYTOKINE PROFILE IN THE TREATMENT OF PATIENTS WITH ACUTE ADHESIVE INTESTINAL OBSTRUCTION IN THE STAGE OF DECOMPENSATION
}

\begin{abstract}
The aim of the work: to study the dynamics of pro- and anti-inflammatory cytokines in patients with acute adhesive intestinal obstruction in the stage of compensation and decompensation and to evaluate the effectiveness of the developed method of complex postoperative treatment.

Materials and Methods. 182 patients with acute adhesive intestinal obstruction were examined. Of these, 152 (83.5 \%) patients were operated on and 30 (16.5\%) patients were treated conservatively (control group). Patients with decompensated bowel obstruction in the postoperative period were treated in the traditional and proposed way, which included lavage, oxygen therapy (Patent of Ukraine for utility model No. 81097) and enteral nutrition through an intubation tube. Intestinal lavage was performed with $0.9 \% \mathrm{NaCl}$ solution, enteral nutrition was started with the appearance of peristalsis with the help of "Peptamen" solution. An additional group of healthy individuals was also examined. For the purpose of serum cytokine status, TNF-a, IL-1 $\beta$, IL-10 were determined by enzyme-linked immunosorbent assay using reagents manufactured by Ukrmedservice, Ukraine.

Results and Discussion. In patients with acute adhesive intestinal obstruction in the stage of decompensation treated by the traditional method, the content of the investigated cytokines (TNF-a, IL-1 $\beta$, IL-10) continues to increase statistically significant up to 3 days postoperatively with a decrease after 5 days. The use of the comprehensive method of postoperative therapy in patients with decompensated acute intestinal obstruction implies a gradual decrease in the content of cytokines from 1 to 5 days postoperative, which corresponds to the positive dynamics of the results of general clinical trials and treatment.
\end{abstract}

Key words: acute adhesive intestinal obstruction; cytokines. 


\author{
А. Д. БЕДЕНЮК, А. Е. БУРАК, Ю. М. ФУТУЙМА
}

Тернопольский национальный медицинский университет имени И. Я. Горбачевского

\title{
УРОВЕНЬ И ДИНАМИКА ПОКАЗАТЕЛЕЙ ЦИТОКИНОВОГО ПРОФИЛЯ ПРИ ЛЕЧЕНИИ БОЛЬНЫХ ОСТРОЙ СПАЕЧНОЙ КИШЕЧНОЙ НЕПРОХОДИМОСТЬЮ В СТАДИИ ДЕКОМПЕНСАЦИИ
}

Цель работы: изучить динамику про- и противовоспалительных цитокинов у больных острой спаечной кишечной непроходимостью в стадии компенсации и декомпенсации и оценить эффективность разработанного метода комплексного послеоперационного лечения.

Материалы и методы. Обследовано 182 больных острой спаечной кишечной непроходимостью. Из них 152 (83,5 \%) пациенты были прооперированы и 30 (16,5 \%) пациентов пролечены консервативно (контрольная группа). Пациентов с декомпенсированной кишечной непроходимостью в послеоперационном периоде лечили традиционным и предложенным нами способом, который включал лаваж, оксигенотерапию (Патент Украины на полезную модель № 81097) и энтеральное питание через интубационный зонд. Лаваж кишки проводили 0,9 \% раствором $\mathrm{NaCl}$, энтеральное питание начинали с появлением перистальтики с помощью раствора “Пептамен”. Также обследовано дополнительную группу здоровых лиц. С целью оценки цитокинового статуса в сыворотке крови определяли содержание TNF $\alpha$, IL1 $\beta$, IL10 методом твердофазного иммуноферментного анализа с помощью реагентов производства ООО “Укрмедсервис”, Украина.

Результаты исследований и их обсуждение. У пациентов с острой спаечной кишечной непроходимостью в стадии декомпенсации, леченных традиционным методом, содержание исследуемых цитокинов (TNF $\alpha$, IL1 $1 \beta$, IL10) продолжает статистически значимо расти до 3 суток послеоперационного периода со снижением через 5 суток. Применение разработанного нами комплексного метода послеоперационной терапии у пациентов с декомпенсированной острой спаечной кишечной непроходимостью приводит к постепенному снижению содержания цитокинов с 1 до 5 суток послеоперационного периода, соответствующего положительной динамике результатов общеклинических исследований и субъективного состояния пациентов и свидетельствует об эффективности разработанного метода лечения.

Ключевые слова: острая спаечная кишечная непроходимость; цитокины. 